\title{
Nondestructive analysis of photosynthetic pigments in forage radish and vetch
}

\author{
Tiago Edu Kaspary ${ }^{1 * \mathbb{D}}$, Luan Cutti ${ }^{2}$, Cristiano Bellée Gabriele Casarotto $^{2}$, Rodrigo Ferraz Ramos ${ }^{3}$
}

10.1590/0034-737X202067060001

\begin{abstract}
Chlorophylls and carotenoids are the main photosynthetic pigments in plants, and photosynthetic potential can be used to determine the nitrogen fixation or cycling capacity of cover crops. Therefore, this study quantified and compared the content of photosynthetic pigments in Raphanus sativus and Vicia sativa by using two different methods, namely the extraction method and measurements with a portable chlorophyll meter, and determined whether the results of these two methods showed a significant correlation. Photosynthetic pigments were measured, using both methods, in a greenhouse and laboratory, at four developmental stages: the vegetative stages I (30 days after sowing [DAS]), II (60DAS), and III (90DAS), and the reproductive stage (150DAS). The determination of the photosynthetic pigment content in R. sativus and V. sativa, obtained from the extraction method and chlorophyll index, revealed significant differences depending on the developmental stage in both species. Furthermore, the contents of chlorophyll a, chlorophyll $\mathrm{b}$, and carotenoids determined using the extraction method showed high coefficients of correlation with the total chlorophyll index determined using the portable chlorophyll meter. Therefore, the portable chlorophyll meter can be used for the accurate evaluation of the photosynthetic potential of Raphanus sativus and Vicia sativa, which also saves time and reagents.
\end{abstract}

Keywords: Raphanus sativus L.; Vicia sativa L; carotenoids; chlorophyll; portable chlorophyll.

\section{INTRODUCTION}

The forage radish (Raphanus sativus L.) and vetch (Vicia sativa L.) are forage species considered important for cultivation during winter in southern Brazil, especially to cover and protect soil with plants, plant residues in notillage systems, and as weed suppressors (Cutti et al., 2016; Krenchinski et al., 2018). The forage radish is mainly used due to its fast growth, low nutrient demand, high tolerance to climatic adversities, and pivotal root system, which increases soil exploration and may improve soil physical conditions, in addition to presenting an intense nutrient cycling rate, with easy availability to the crop in succession (Cardoso et al., 2014; Krenchinski et al., 2018). As for the vetch, it is widely used because of its considerable nitrogen fixation capacity and rapid availability to next crops, which is illustrated by the fact that it can provide more than $200 \mathrm{~kg}$ of nitrogen per hectare (Restovich et al., 2012).

In current agriculture, the photosynthetic efficiency of crop plants is used to determine the rate of nitrogen fertilization or the potential amount of nitrogen that cover crops can bring to the next crop because the total chlorophyll content is associated with the organic nitrogen content of leaves and, consequently, crop yield in many crops (Smeal \& Zhang, 1994; Rigon et al., 2012; De Castro et al., 2014; Cavalcante et al., 2016; Kaspary et al., 2019).

The content of photosynthetic pigments are measured mostly using the traditional methodology, which implies the destruction of leaf samples. This procedure is costly as it involves the use of laboratory reagents, and it is impractical because it does not produce instant results.

\footnotetext{
Submitted on June $19^{\text {th }}, 2019$ and accepted on August $21^{\text {th }}, 2020$.

'Instituto Nacional de Investigación Agropecuaria del Uruguay - INIA la Estanzuela, Colonia, Uruguay. tkaspary@inia.org.uy

${ }^{2}$ Universidade Federal do Rio Grande do Sul, Faculdade de Agronomia, Departamento de Fitotecnia, Porto Alegre, Rio Grande do Sul, Brazil. luancutti@hotmail.com; gabrielecasarotto@gmail.com

${ }^{3}$ Universidade Federal de Santa Maria, Centro de Ciências Rurais, Santa Maria, Rio Grande do Sul, Brazil. crbelle@gmail.com; rodrigoferrazramos@gmail.com

*Corresponding author: tkaspary@inia.org.uy
} 
In contrast, portable chlorophyll meters rely on nondestructive, simple, and instantaneous measurements (Salla et al., 2007). In recent years, portable chlorophyll meters have been successfully used to measure the content of photosynthetic pigments and leaf nitrogen content in different species (Ciganda et al., 2009; Rigon et al., 2012; Rigon et al., 2013; Kaspary et al., 2014b; Kaspary et al., 2019).

Chlorophyll meters indirectly determine the relative chlorophyll content, which is calculated from the amount of light transmitted by the leaf, measured at wavelengths with variable absorbance, hence providing a unique reading that is proportional to the contents of chlorophyll a, chlorophyll b, and carotenoids (Minolta Camera Company, 1989; Falker Automação Agrícola, 2009). Models of chlorophyll meters describe the relationship between the readings displayed by the portable chlorophyll meter and extractable chlorophyll according to species and their intrinsic characteristics, which requires independent calibration (Lee, 1988; Markwell et al., 1995; Uddling et al., 2007). To date, no studies have been conducted to understand the relationship between different methods for the measurement of photosynthetic pigments in $R$. sativus and V. sativa.

The objective of the present study was to quantify and compare the content of photosynthetic pigments in the cover crops Raphanus sativus and Vicia sativa using two different methods, namely the extraction method and measurements with a portable chlorophyll meter, and to determine whether the results of these methods were significantly correlated.

\section{MATERIALS AND METHODS}

\section{Plant material}

This study was conducted in a greenhouse and in the Laboratory of Chemical Analysis of the Department of Agronomic and Environmental Sciences of the Universidade Federal de Santa Maria (UFSM), Campus of Frederico Westphalen, RS - Brazil, from May 2013 to November 2013. Seeds of $R$. sativus and $V$. sativa were sown in $6 \mathrm{~L}$ plastic pots filled with agricultural substrate. After seed germination, only one seedling was retained per pot. Photosynthetic pigments were measured, using both methods, at four developmental stages: the vegetative stages I (30 days after sowing [DAS]), II (60 DAS), and III (90 DAS), and the reproductive stage (150 DAS). To measure the photosynthetic pigments at each developmental stage, two leaves from the middle third of the main stalk of the same plant were analyzed and collected. For each species, this procedure was repeated with four plants, totaling eight replicates per treatment.

\section{Estimation of pigment content}

The relative chlorophyll content was measured individually using a ClorofiLOG $1030^{\circledR}$ (Falker, Porto Alegre, Brazil) portable meter, and the index reading was obtained directly from the leaf without removing it from the plant. The relative chlorophyll content determined using the portable chlorophyll meter was calculated from the amount of light transmitted by the leaf, based on the wavelength with variable absorbance, thus instantaneously providing a single reading proportional to the content of chlorophyll a, chlorophyll b, and carotenoids (Rigon et al., 2012). Notably, the portable ClorofiLOG1030 meter operates at the following three wavelengths: 635, 660, and $850 \mathrm{~nm}$ (Rigon et al., 2012).

\section{Measurement of chlorophyll using a destructive method}

Leaves of $R$. sativum and V. sativa were collected and taken to the laboratory for analysis with the extraction methodology, as described previously (Hiscox \& Israelstam, 1979). To dissolve the samples, $0.05 \mathrm{~g}$ of fresh leaf weight (FLW) was placed in test tubes containing 3 $\mathrm{mL}$ of dimethyl sulfoxide (DMSO) and incubated in a water bath at $65^{\circ} \mathrm{C}$ for $45 \mathrm{~min}$. Subsequently, $2 \mathrm{~mL}$ of DMSO was added, and samples were manually shaken for $30 \mathrm{~s}$. Then, the absorbance of the final solution $(2.5 \mathrm{~mL})$ containing the pigments was measured using a BioMate3 spectrophotometer (ThermoFischer, Madison, WI, USA) at 470, 645, and $663 \mathrm{~nm}$ for carotenoids, chlorophyll b, and chlorophyll a, respectively. Readings obtained at each wavelength were used in the equations reported by Lichtenthaler (1987), based on the FLW, to determine the content of total chlorophyll, chlorophyll a, chlorophyll b, and carotenoids, in $\mathrm{mg} \mathrm{g}^{-1}$.

\section{Statistical analysis}

The data obtained for $R$. sativus and $V$. sativa using the two methods were subjected to analysis of variance using the F test, and the means of the treatments were compared using the DMS test, with a 5\% probability level. The correlation between the readings obtained using the extraction method and with the portable chlorophyll meter was assessed with a regression analysis. Curve adjustments were performed with the quadratic function, according to the determination coefficient, using Sigmaplot $^{\circledR}$ version 11.2.

\section{RESULTS}

\section{Nondestructive method of chlorophyll measurement}

The results obtained in the present work demonstrated that the chlorophyll content measured with the portable chlorophyll meter varied significantly with the 
developmental stage of $R$. sativus and $V$. sativa $(P \geq 0.05$ for both; Table 1). For $R$. sativus, the chlorophyll index measured at the vegetative stage I was the lowest (i.e., 43.0), whereas that measured at the vegetative stage II was the highest (i.e., 49.6). As for $V$. sativa, the mean chlorophyll index measured at the vegetative stage III was the highest (i.e., 50.4), whereas that measured at the reproductive stage was the lowest (i.e., 40.1). Notably, the chlorophyll index measured during the reproductive stage of $R$. sativus was intermediate between the indices measured during other stages, with a value of 47.2.

\section{Destructive method of chlorophyll measurement in the laboratory}

The evaluation of the photosynthetic pigments in $R$. sativus and $V$. sativa with the extraction method revealed that the contents of chlorophyll a, chlorophyll b, total chlorophyll, and carotenoids varied with the developmental stage of the plants (Table 1). For R. sativus, these contents were the lowest at the reproductive stage ( 1.0358, 0.2456, and $2814 \mathrm{mg} \mathrm{g}^{-1}$ FLW for chlorophyll a, chlorophyll b, total chlorophyll, and carotenoids, respectively) and highest at the vegetative stage III (1.4603, 0.2949, 1.8552, and $0.4487 \mathrm{mg} \mathrm{g}^{-1}$ FLW for chlorophyll a, chlorophyll b, and total chlorophyll, respectively; Table 1). At the other stages, the values of these pigments were intermediate, with the exception of carotenoids, whose values did not differ between the vegetative stages I and II and the reproductive stage.

For V. sativa, the contents of chlorophyll a, chlorophyll b, total chlorophyll, and carotenoids at the vegetative stage III were $1.9958,0.3025,2.2983$, and $0.4705 \mathrm{mg} \mathrm{g}^{-1}$ FLW, respectively, thus revealing superior photosynthetic performance at this stage (Table 1). The values of these pigments were intermediate during the vegetative stage I and reproductive stage. These data indicate a greater accumulation of photosynthetic pigments in $R$. sativus than in $V$. sativa.

\section{Comparison between the destructive and nondestructive methods of chlorophyll measurement}

The regression analysis of the results obtained using two different methodologies (i.e., measurements with the portable chlorophyll meter and the laboratory extraction method) showed a high correlation, with all determination coefficients above 0.75 (Figures 1 and 2). The correlation between the chlorophyll index for chlorophyll a generated with the chlorophyll meter and that measured with the laboratory extraction method was high, with determination coefficients of 0.85 and 0.91 for $R$. sativus and $V$ sativa, respectively (Figures 1A and 1B). For chlorophyll b, the data showed a quadratic behavior and determination coefficients of 0.90 and 0.92 for forage radish and vetch, respectively (Figures 1C and 1D). Finally, the chlorophyll index obtained with the chlorophyll meter showed a high capacity to indirectly measure the total chlorophyll content in both species, with determination coefficients of 0.90 and 0.93 for $R$. sativus and V. sativa, respectively (Figures $1 \mathrm{E}$ and $1 \mathrm{~F})$.

The measurement of carotenoids using the laboratory extraction method was strongly correlated with the chlorophyll index obtained with the chlorophyll meter, with determination coefficients of 0.94 and 0.90 for $R$. sativus and $V$. sativa, respectively (Figures $2 \mathrm{~A}$ and $2 \mathrm{~B}$ ). Based on the high determination coefficients, the chlorophyll a and b contents could be correlated with the indices determined using the chlorophyll meter, and a highly reliable mathematical model was developed for these variables, when analyzed in $R$. sativus and $V$. sativa (Figures $2 \mathrm{C}$ and 2D).

\section{DISCUSSION}

The results indicated that the chlorophyll index increased in the vegetative stage III for both $R$. sativus and $V$. sativa, before subsequently decreasing in the reproductive stage (Table 1). A higher photosynthetic pigment content facilitates the use of luminosity to increase the rate of liquid accumulation of photoassimilates, which is also linked to a high vegetative growth rate (Fleck et al., 2003). This suggests that forage radish and vetch present a similar capacity to utilize luminosity in the vegetative stages I, II, and III, thus increasing the accumulation of dry matter as well as their competitive potential.

The results of the measurement of photosynthetic pigments using the laboratory extraction method corroborated the results obtained with the chlorophyll meter (Table 1). Notably, such correspondence has also been reported in studies that compared the ClorofiLOG index and laboratory extraction with Sesamum indicum, Ricinus communis, Conyza bonariensis, Avena strigosa, and Avena sativa (Rigon et al., 2012; Rigon et al., 2013; Kaspary et al., 2014a; Kaspary et al., 2019).

High correlations were observed between the two measurement methods for all the analyzed photosynthetic pigments (Figures 1 and 2). For instance, the correlation for chlorophyll a was high in the present study, with a determination coefficient of 0.91 for $R$. sativus and $V$. sativa, which is similar to the results of previous studies on $L$. multiflorum and A. strigose that obtained determination coefficients of 0.98, 0.96, and 0.91, respectively (Kaspary et al., 2014b; Kaspary et al., 2019). Thus, we conclude that it is possible to efficiently estimate the chlorophyll a content using portable chlorophyll meters and mathematical models that have been developed in parallel 
with the laboratory extraction method (Kaspary et al., 2019). In other words, it is an important tool to assess the photosynthetic potential of these species and to infer their nutritional status (Coelho et al., 2012). The nutritional status of plants, which is related to nitrogen availability, can be gauged with chlorophyll indices because nitrogen is part of the structure of chlorophyll (Coelho et al., 2010). In tomatoes, for example, a study showed that the chlorophyll index varied proportionally to the different rates of nitrogen fertilization that were used (Coelho et al., 2010). Therefore, the photosynthetic capacity of the plant as well as its potential for accumulation of photoassimilates and development, can be inferred from the chlorophyll index.

High determination coefficients for chlorophyll $b$ ( $>0.90$ for forage radish and vetch) between the chlorophyll index and the results of the laboratory extraction method corroborate those previously observed in $C$. bonariensis
(>0.90 in the two evaluated biotypes; Kaspary et al., 2014a). Notably, with chlorophyll meters, measuring the chlorophyll b content is more difficult than measuring the chlorophyll a content (Neves et al., 2005) because the wavelength emitted by the apparatus is closer to the absorption peak of chlorophyll a (i.e., $660 \mathrm{~nm}$ ), whereas the absorption of chlorophyll $b$ has two peaks (i.e., 500 and $650 \mathrm{~nm}$; Di Vittorio, 2009). However, in the present study, high efficiency was observed in the ClorofiLOG readings, in relation to the laboratory analyses, for $R$. sativus and V. sativa. Similarly, high reliability coefficients for chlorophyll $\mathrm{b}$ were obtained with ClorofiLOG readings in previous studies on L. multiflorum, A. strigose, and A. sativa (Kaspary et al., 2014b; Kaspary et al., 2019).

The total chlorophyll content also showed a high correlation with the chlorophyll index, with determination coefficients of 0.90 and 0.92 for $R$. sativus and $V$. sativa, respectively (Figures $1 \mathrm{E}$ and $1 \mathrm{~F}$ ). These values are similar

Table 1: Relative chlorophyll index generated by the ClorofiLOG meter, and chlorophyll a, chlorophyll b, total chlorophyll, and carotenoids (FLW mg g"1) obtained with the extraction method, in R. sativus and V. sativa.

\begin{tabular}{|c|c|c|c|c|}
\hline \multicolumn{5}{|c|}{ Chlorophyll index } \\
\hline & Vegetative - I & Vegetative - II & Vegetative - III & Reproductive \\
\hline Raphanus sativus & $43.0 \mathrm{~B}^{2}$ & $49.6 \mathrm{~A}$ & $51.3 \mathrm{~A}$ & $47.2 \mathrm{AB}$ \\
\hline $\mathrm{CV}(\%)^{1}$ & \multicolumn{4}{|c|}{8.93} \\
\hline Vicia sativa & $42.9 \mathrm{~B}$ & $45.4 \mathrm{AB}$ & $50.4 \mathrm{~A}$ & $40.1 \mathrm{~B}$ \\
\hline $\mathrm{CV}(\%)$ & \multicolumn{4}{|c|}{7.23} \\
\hline \multicolumn{5}{|c|}{ Chlorophyll $a$} \\
\hline Raphanus sativus & $1.1174 \mathrm{~B}$ & $1.4273 \mathrm{~A}$ & $1.4603 \mathrm{~A}$ & $1.0358 \mathrm{~B}$ \\
\hline $\mathrm{CV}(\%)$ & \multicolumn{4}{|c|}{5.64} \\
\hline Vicia sativa & $1.1046 \mathrm{~B}$ & $1.2298 \mathrm{~B}$ & $1.9958 \mathrm{~A}$ & $1.0088 \mathrm{~B}$ \\
\hline $\mathrm{CV}(\%)$ & \multicolumn{4}{|c|}{8.91} \\
\hline \multicolumn{5}{|c|}{ Chlorophyll $b$} \\
\hline & Vegetative - I & Vegetative - II & Vegetative - III & Reproductive \\
\hline Raphanus sativus & $0.2658 \mathrm{AB}$ & $0.2623 \mathrm{AB}$ & $0.2949 \mathrm{~A}$ & $0.2456 \mathrm{~B}$ \\
\hline $\mathrm{CV}(\%)$ & \multicolumn{4}{|c|}{8.04} \\
\hline Vicia sativa & $0.2296 \mathrm{~B}$ & $0.2036 \mathrm{~B}$ & $0.3025 \mathrm{~A}$ & $0.1977 \mathrm{~B}$ \\
\hline $\mathrm{CV}(\%)$ & \multicolumn{4}{|c|}{8.74} \\
\hline \multicolumn{5}{|c|}{ Chlorophyll total } \\
\hline & Vegetative - I & Vegetative - II & Vegetative - III & Reproductive \\
\hline Raphanus sativus & $1.3832 \mathrm{~B}$ & $1.6896 \mathrm{~A}$ & $1.8552 \mathrm{~A}$ & $1.2814 \mathrm{~B}$ \\
\hline $\mathrm{CV}(\%)$ & \multicolumn{4}{|c|}{12.01} \\
\hline Vicia sativa & $1.3342 \mathrm{~B}$ & $1.4334 \mathrm{~B}$ & $2.2983 \mathrm{~A}$ & $1.2065 \mathrm{~B}$ \\
\hline $\mathrm{CV}(\%)$ & \multicolumn{4}{|c|}{7.45} \\
\hline \multicolumn{5}{|c|}{ Carotenoids } \\
\hline & Vegetative - I & Vegetative - II & Vegetative - III & Reproductive \\
\hline Raphanus sativus & $0.2875 \mathrm{~B}$ & $0.3647 \mathrm{~B}$ & $0.4487 \mathrm{~A}$ & $0.3648 \mathrm{~B}$ \\
\hline $\mathrm{CV}(\%)$ & \multicolumn{4}{|c|}{10.01} \\
\hline Vicia sativa & $0.3823 \mathrm{~B}$ & $0.4198 \mathrm{~B}$ & $0.4705 \mathrm{~A}$ & $0.3596 \mathrm{C}$ \\
\hline $\mathrm{CV}(\%)$ & \multicolumn{4}{|c|}{6.75} \\
\hline
\end{tabular}

${ }^{1}$ Coefficient of variation. ${ }^{2}$ Similar uppercase letters in the row do not differ from one another by the DMS test at $5 \%$ significance. 
to those obtained using the correlation method with Gossypium hirsutum and S. indicum, with coefficients of 0.91 and 0.98, respectively (Brito et al., 2011; Rigon et al., 2012). This confirms that it is possible to adjust a highly reliable mathematical model for this variable when comparing pigment measurements that were performed, in forage radish and vetch, using different methods (Figures $1 \mathrm{E}$ and $1 \mathrm{~F})$.

\section{Raphanus sativus}

A.

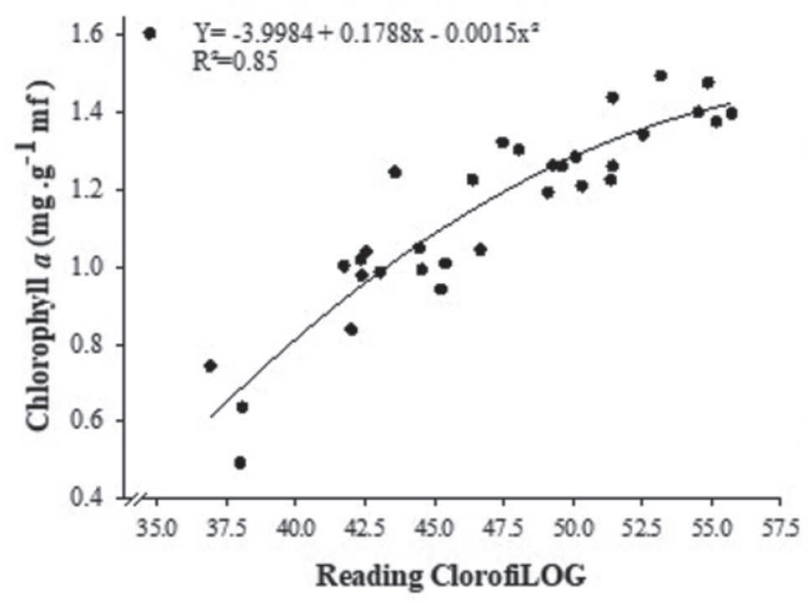

C.

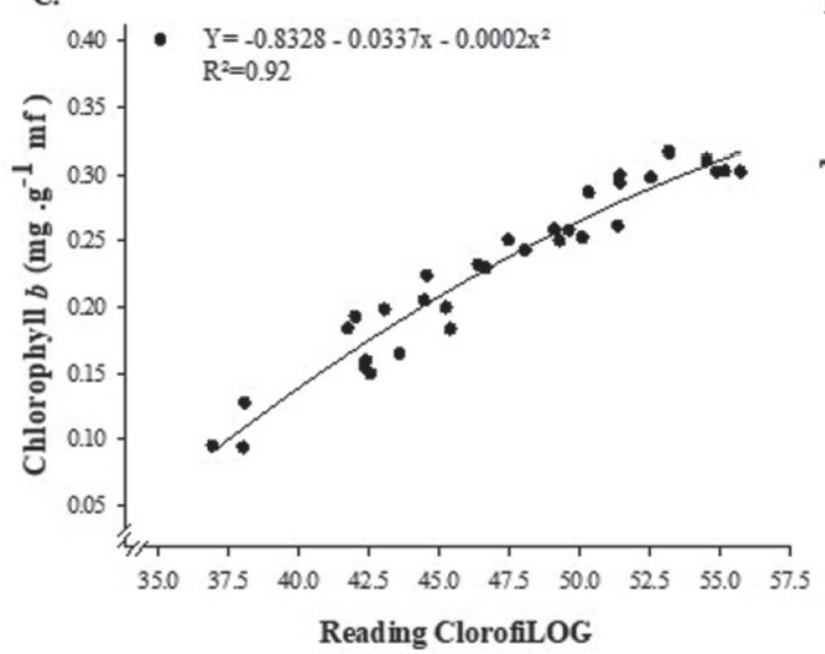

E.

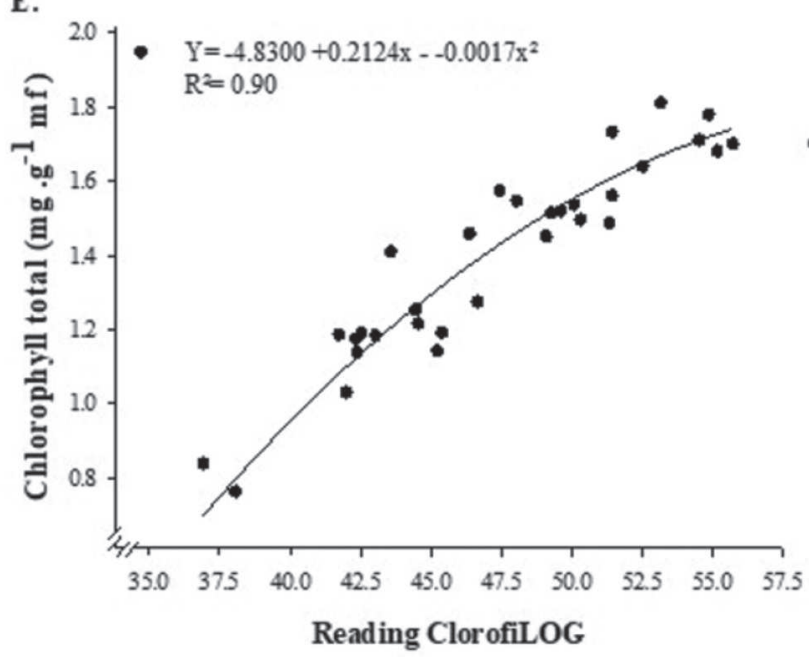

Vicia sativa

B.

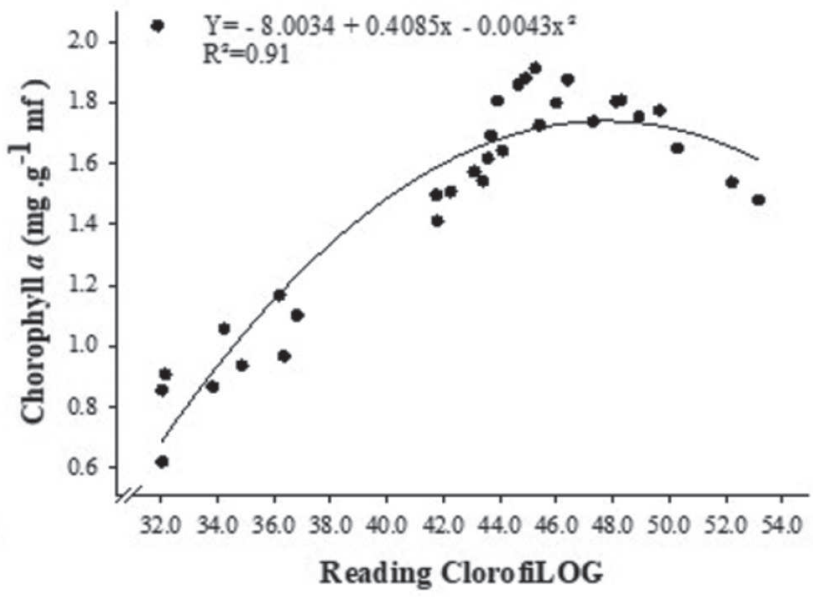

D.

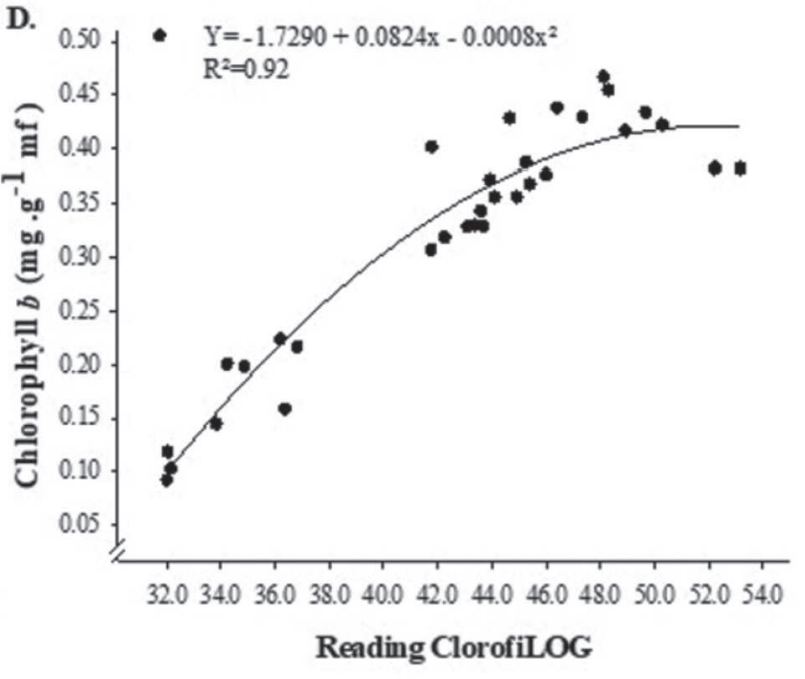

F.

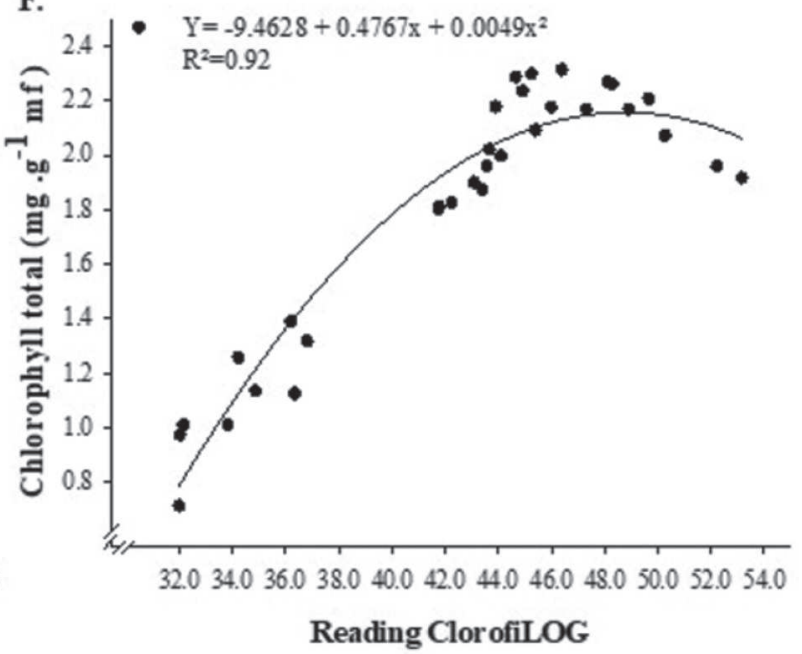

Figure 1: Relationship between the readings of the portable ClorofiLOG for chlorophyll a, chlorophyll b, and total chlorophyll contents in R. sativus (A, C, and $\mathrm{E}$ ) and V. sativa (B, D, and F). 
The relationship between chlorophyll and carotenoid contents of leaves in $R$. sativus and $V$. sativa, shown in Figures $2 \mathrm{~A}$ and $2 \mathrm{~B}$, present equations of high representativeness $\left(\mathrm{R}^{2}>0.90\right.$ for forage radish and vetch), enabling the estimation of the actual content of these plant pigments from the readings of the ClorofiLOG meter. Notably, similar results have been reported for corn and cotton (Ciganda et al., 2009; Brito et al., 2011). Measuring carotenoids is important because these pigments act as photoprotectors in photosystem II and dissipate excess light energy, and, owing to their high antioxidant potential, they prevent chlorophyll damage (Li et al., 2010). Furthermore, the ratio of chlorophyll to carotenoid is altered under stress conditions, especially under water stress (Young \& Britton, 1990). Thus, the rapid and accurate measurement of carotenoid content helps infer the state of the plant. Using reliable models, the carotenoid content in $R$. sativus and $V$. sativa can be determined from the readings obtained with portable chlorophyll meters.

The correlation analysis between the chlorophyll index measured with the ClorofiLOG meter and the extracted chlorophyll a and b contents measured using the laboratory extraction method revealed high determination coefficients, namely 0.75 and 0.87 for $R$. sativus and $V$. sativa, respectively. The relationship between chlorophyll $\mathrm{a}$ and chlorophyll $\mathrm{b}$ is important in assessing the ability of plants to capture light under shade conditions (Nakazono et al., 2001). In the present study, the results for the forage radish and vetch are similar to those previously observed for $R$. communis, A. strigosa, and A. sativa, which were characterized by determination coefficients of $0.70,0.89$, and 0.87 , respectively (Rigon et al., 2012; Kaspary et al., 2019).

Overall, the measurement of photosynthetic pigments in $R$. sativus and $V$. sativa using a portable chlorophyll

\section{Raphanus sativus}

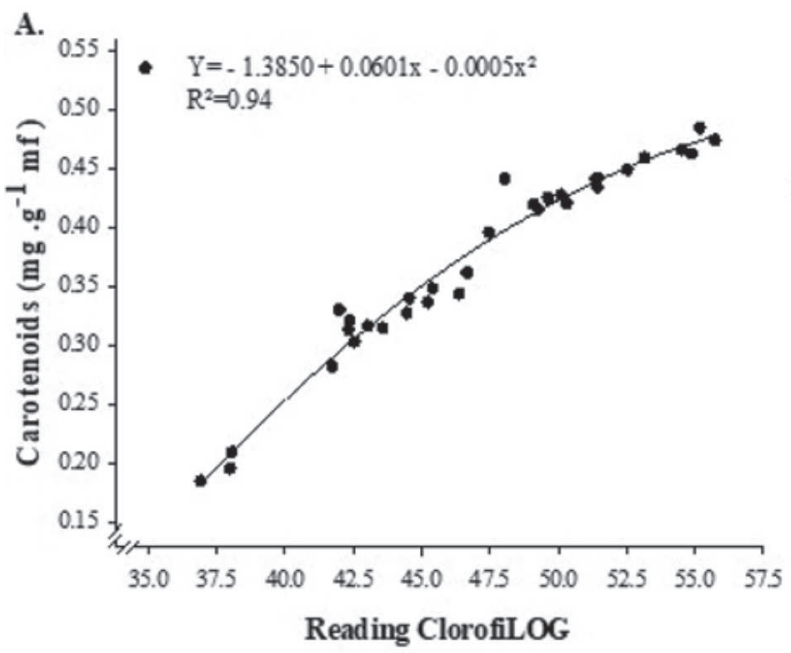

C.

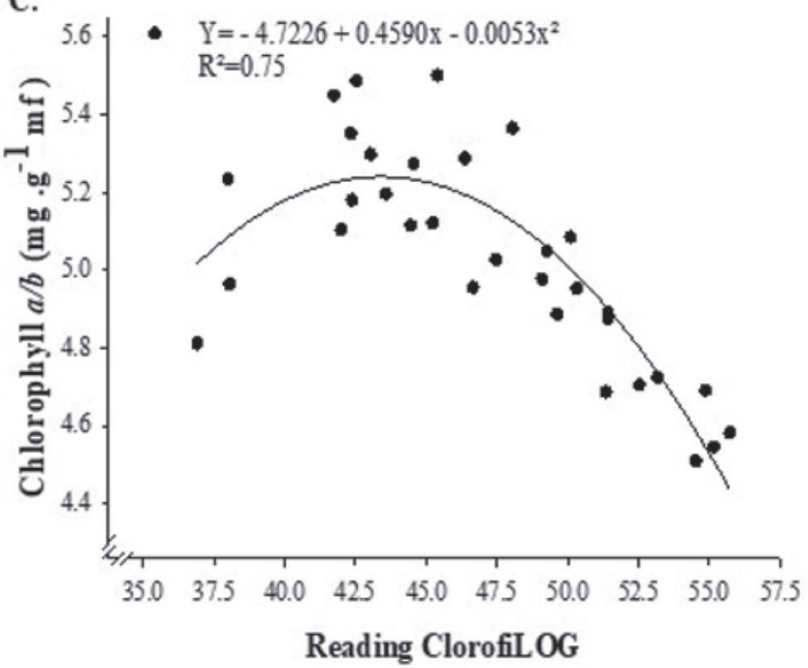

Vicia sativa

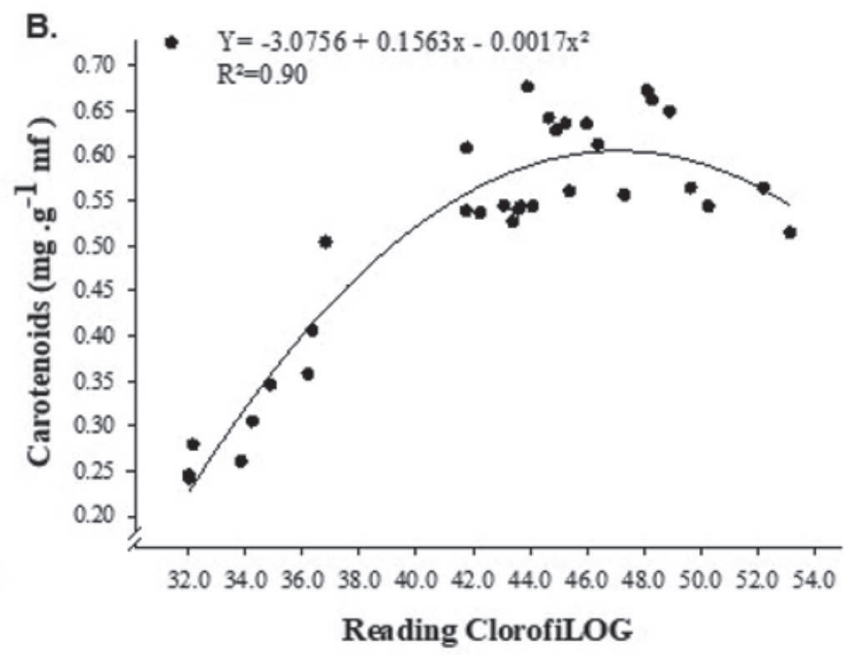

D.

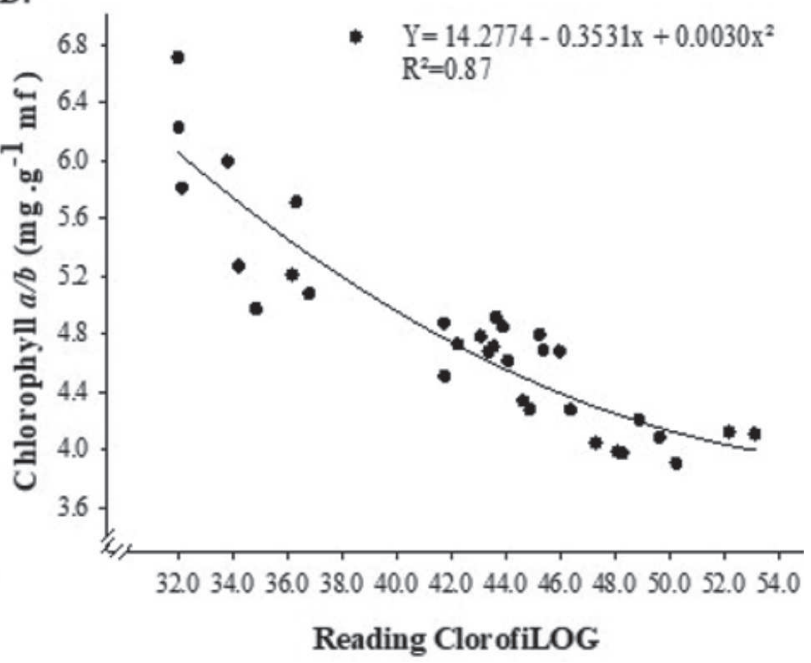

Figure 2: Relationship between the readings of the portable ClorofiLOG for carotenoid contents and chlorophyll a/b ratio in $R$. sativus (A and $\mathrm{C}$ ) and V. sativa (B and D). 
meter and adjusted mathematical models is accurate, efficient, and economical in comparison to the laboratory extraction method. Thus, the chlorophyll meter is an important tool to determine the photosynthetic potential of forage radish and vetch.

\section{CONCLUSION}

The determination of the photosynthetic pigment content in $R$. sativus and $V$. sativa with the extraction method and chlorophyll index revealed significant differences in pigment levels depending on the developmental stage, in both species.

The measurement of the photosynthetic pigments in $R$. sativus and $V$. sativa using a portable chlorophyll meter and adjusted mathematical models is accurate and saves time and reagents compared to the laboratory extraction method.

\section{ACKNOWLEDGEMENTS, FINANCIAL SUPPORT AND FULL DISCLOSURE}

To the Fundação de Amparo à Pesquisa do Estado do Rio Grande do Sul - FAPERGS, for the funding of this research.

We have no conflict of interest to declare.

\section{REFERENCES}

Brito GG, Sofiatti V, Brandão ZN, Silva VB, Silva FM \& Silva DA (2011) Non-destructive analysis of photosynthetic pigments in cotton plants. Acta Scientiarum Agronomy, 33:671-678.

Cardoso RA, Bento AS, Moreski HM \& Gasparotto F (2014) Influência da adubação verde nas propriedades físicas e biológicas do solo e na produtividade da cultura de soja, Semina. Ciências Biológicas e da Saúde, 35:51-60.

Cavalcante IHL, Silva Júnior GB, Santos EM \& Lima AMN (2016) Relationship between chlorophyll meter readings and leaf nitrogen concentration in papaya (Carica papaya L.). Philipp Journal of Crop Science, 41:75-79.

Ciganda V, Gitelson A \& Schepers J (2009) Non-destructive determination of maize leaf and canopy chlorophyll content. Journal of Plant Physiology, 166:157-167.

Coelho FS, Fontes PCR, Finger FL \& Cecon PR (2012) Avaliação do estado nutricional do nitrogênio em batateira por meio de polifenóis e clorofila na folha. Pesquisa Agropecuária Brasileira, 47:584-592.

Coelho FS, Fontes PCR, Puiatti M, Neves JCL \& Silva MC (2010) Dose de nitrogênio associada à produtividade de batata e índices do estado de nitrogênio na folha. Revista Brasileira de Ciência do Solo, 34:1175 1183.

Cutti L, LamegoFP, Aguiar ACM, Kaspary TE \& Rigon CAG (2016) Winter cover crops on weed infestation and maize yield. Caatinga, 29:885-891.

De Castro FA, Campostrini E, Netto AT, Gomes MMA, Ferraz TM \& Glenn TM (2014) Portable chlorophyll meter (PCM502) values are related to total chlorophyll concentration and photosynthetic capacity in papaya (Carica papaya $\mathrm{L})$. Theoretical and Experimental Plant Physiology, 26:201-210.
Di Vittorio AV (2009) Enhancing a leaf radiative transfer model to estimate concentrations and in-vivo speciû c absorption coefû cients of total carotenoids and chlorophylls a and b from singleneedle reû ectance and transmittance. Remote Sensing of Environment, 113:1948-1966.

Falker - Automação agrícola (2009) Medidor eletrônico de teor de clorofila: dados técnicos clorofiLOG CFL1030. Available at: http://www.falker.com.br/ download.php?file_id=74>. Accessed on: June $18^{\text {th }}, 2020$.

Fleck NG, Balbinot-Junior AA, Agostinetto D \& Rizzardi MA (2003) Velocidade de estabelecimento em cultivares de arroz irrigado como característica para aumentar a habilidade competitiva com plantas concorrentes. Ciência Rural, 33:635-640.

Hiscox JD \& Israelstam GF (1979) A method for the extraction of chlorophyll from leaf tissue without maceration. Canadian Journal \& Botany, 57:1132-1334.

Kaspary TE, Cutti L, Bellé C, Casarotto G, Groth MZ, Silva GBP \& Aguiar ACM (2019) Non-destructive analysis of photosynthetic pigments in Avena strigosa and Avena sativa. Australian Journal of Crop Science, 13:354-359.

Kaspary TE, Lamego FP, Cutti L, Aguiar ACM \& Bellé C (2014a) Determination of photosynthetic pigments in fleabane biotypes susceptible and resistant to the herbicide glyphosate. Planta Daninha, 32:417-426.

Kaspary TE, Lamego FP, Peruzzo ST, Pagliarini IB \& Rigon CAG (2014b) Pigmentos fotossintéticos em azevém suscetível e resistente ao herbicida glyphosate. Ciência Rural, 44:1901-1907.

Krenchinski FH, Cesco VJS, Rodrigues DM, Albrecht LP, Wobeto KS \& Albrecht AJP (2018) Agronomic performance of soybean grown in succession to winter cover crops. Pesquisa Agropecuária Brasileira, 53:909-917.

Lee DW (1988) Simulating forest shade to study the development ecology of tropical plants: Juvenile growth in three vines in India. Journal Tropical Ecology, 4:281-292.

LI R, Shi F, Fukuda K \& Yang Y (2010) Effects of salt and alkali stresses on germination, growth, photosynthesis and ion accumulation in alfalfa (Medicago sativa L.). Soil Science \& Plant Nutrition, 56:725-733.

Lichtenthaler HK (1987) Chlorophylls and carotenoids: pigments of photosynthetic biomembranes. In: Packer L \& Douce R (Eds) Methods in enzymology. New York, Academic Press. p. 350-382.

Markwell J, Osterman JC \& Mitchell JL (1995) Calibration of the Minolta SPAD-502 leaf chlorophyll meter. Photosynthesis Research, 46:467-472.

Minolta Camera Company (1989) Chlorophyll meter SPAD-502 - Instruction Manual. Osaka, Minolta. 22p.

Nakazono EM, Costa MC, Futatsugi K \& Paulilo MTS (2001) Crescimento inicial de Euterpe edulis Mart. em diferentes regimes de luz. Revista Brasileira de Botânica, 24:173-179.

Neves OSC, Carvalho JG, Martins FA, Pádua TRP \& Pinho PJ (2005) Uso do SPAD-502 na avaliação dos teores foliares de clorofila, nitrogênio, enxofre, ferro e manganês do algodoeiro herbáceo. Pesquisa Agropecuária Brasileira, 40:517-521.

Restovich SB, Andriulo AE \& Portela SI (2012) Introduction of cover crops in a maize-soybean rotation of the Humid Pampas: Effect on nitrogen and water dynamics. Field Crops Research, 128:62-70.

Rigon JPG, Beltrão NEM, Capuani S, Brito Neto JF \& Silva FVF (2012) Análise não destrutiva de pigmentos fotossintéticos em folhas de gergelim. Revista Brasileira de Engenharia Agrícola e Ambiental, 16:258-261. 
Rigon JPG, Capuani S, Brito Neto JF \& Beltrão MDM (2013) Indirect measurement of photosynthetic pigments in the leaves of Jatropha curcas. Semina. Ciencias Agrárias, 34:669-674.

Salla L, Rodrigues JC \& Marenco AR (2007) Teores de clorofila em árvores tropicais determinados com SPAD-502. Revista Brasileira de Biociências, 5:59-161.

Smeal D \& Zhang H (1994) Chlorophyll meter evaluation for nitrogen management in corn. Communications in Soil Science and Plant Analysis, 25:1495-1503.
Uddling J, Gelang-Alfredsson J, Piikki K \& Pleuel H (2007) Evaluating the relationship between leaf chlorophyll concentration and SPAD-502 chlorophyll meter readings. Photosynthesis Research, 91:37-46.

Young A \& Britton G (1990) Carotenoids and stress. In: Alscher RG (Ed.) Stress responses in plants: Adaptation and acclimation mechanisms. New York, Wiley-Liss. p. 87-112. 